\title{
Resveratrol suppresses human cervical carcinoma cell proliferation and elevates apoptosis via the mitochondrial and p53 signaling pathways
}

\author{
LIN LI $^{1}$, RONG-LI QIU ${ }^{1}$, YU LIN $^{2}$, YING CAI $^{3}$, YONG BIAN $^{1}$, YAN FAN $^{1}$ and XIAO-JUN GAO ${ }^{1}$ \\ ${ }^{1}$ Institute of Pharmacy, Nanjing University of Chinese Medicine, Nanjing, Jiangsu $210023 ;{ }^{2}$ CAS Key Laboratory of \\ Analytical Chemistry for Living Biosystems, Institute of Chemistry, Chinese Academy of Sciences, Beijing 100190; \\ ${ }^{3}$ Nanjing General Hospital of Nanjing Military Command, Nanjing, Jiangsu 210002, P.R. China
}

Received August 8, 2015; Accepted January 19, 2017

DOI: $10.3892 / \mathrm{ol} .2018 .8571$

\begin{abstract}
Numerous studies have demonstrated the apoptotic and anti-proliferative effects of resveratrol, a natural polyphenolic phytoalexin, on various cancer cell lines. However, the effects of resveratrol on the regulation of human cervical carcinoma, and the mechanisms underlying these effects, remain to be elucidated. In the present study, the potential mechanisms underlying the effects of resveratrol in HeLa cervical carcinoma cells were investigated. The results revealed that resveratrol inhibited proliferation and induced apoptosis in HeLa human cervical cancer cells in a dose-dependent and time-dependent manner. Resveratrol induced cell shrinkage in HeLa cells and apoptosis accompanied by the activation of caspase-3 and -9 . Furthermore, resveratrol upregulated the expression of the pro-apoptotic B-cell lymphoma (Bcl)-2-associated X protein and downregulated the expression of the anti-apoptotic proteins Bcl-2 and Bcl-extra large in HeLa cells. In addition, p53, a protein that is essential for cell survival and cell cycle progression, exhibited elevated expression levels in resveratrol-treated HeLa cells. Therefore, resveratrol may be a promising novel inhibitor of human cervical cancer.
\end{abstract}

\section{Introduction}

Resveratrol (3,5,4'-trihydroxy-trans-stilbene; Fig. 1) is a polyphenolic phytoalexin that is naturally present in food products, including grapes, mulberries and peanuts (1), with demonstrated cardioprotective (2), neuroprotective (3) and anti-inflammatory effects (4). Although these effects are partly attributed to its antioxidant properties, resveratrol has also

Correspondence to: $\mathrm{Mr}$. Yu Lin, CAS Key Laboratory of Analytical Chemistry for Living Biosystems, Institute of Chemistry, Chinese Academy of Sciences, 2 Zhongguancun North First Street, Beijing 100190, P.R. China

E-mail: linyu@iccas.ac.cn

Key words: resveratrol, HeLa, apoptosis, mitochondrial signaling pathway, p53 been demonstrated to produce anti-carcinogenic effects (5). A number of previous studies have revealed the anti-proliferative and apoptotic effects of resveratrol in various cancer cell lines including breast (6-9), lung and prostate cancer (10-12).

Human cervical carcinoma is the most common type of cancer in females, accounting for $\sim 8 \%$ of all newly diagnosed cancer cases globally (13). However, the effects of resveratrol on the regulation of human cervical carcinoma, and the mechanisms underlying such effects, remain to be established. In the present study, resveratrol treatment induced apoptosis in the HeLa human cervical cancer cell line. Furthermore, resveratrol activated the mitochondrial apoptotic signaling pathway and upregulated the expression of caspase-3 and -9. In addition, resveratrol was able to induce cell cycle arrest at the $\mathrm{G}_{2}$ phase and the expression of p53 was upregulated in resveratrol-treated HeLa cells. These data indicate that resveratrol is able to induce cell death in HeLa human cervical cancer cells through various potential underlying mechanisms.

\section{Materials and methods}

Reagents and cell lines. Resveratrol was purchased from The National Institute for the Control of Pharmaceutical and Biological Products (Beijing, China), and dissolved in sterile dimethyl sulfoxide (DMSO) to prepare a stock solution, which was further diluted in fresh Dulbecco's Modified Eagle's Medium (DMEM; Gibco; Thermo Fisher Scientific, Inc., Waltham, MA, USA) and the final concentrations of resveratrol used were $0,5,10,20$ or $40 \mu \mathrm{M}$. The final concentration of DMSO in all cell cultures was $<0.01 \%$. P53 antibody (cat. no. 38007) was purchased from Signalway Antibody (College Park, MA, USA) and B-cell lymphoma 2 (Bcl-2) (cat. no. sc-7382), Bcl-2-associated X protein (Bax) (cat. no. sc-7480), Bcl-extra large (XL; cat. no. sc-8392), caspase-3 (cat. no. sc-7272), $\beta$-actin (cat.no. sc-8432) and were purchased from Santa Cruz Biotechnology, Inc. (Dallas, TX, USA). Goat anti-mouse horseradish peroxidase (HRP)-conjugated antibody (cat. no. G-21040; dilution, 1:1,000) and protein ladder (cat. no. SM0671) were purchased from Thermo Fisher Scientific, Inc. The P53 antibody was diluted at a ratio of 1:1,000 when the antibody incubated with the target protein in 
the NC membrane, while the primary antibodies were diluted at a ratio of 1:500. The experimental protocol was approved by the Research Ethics Committee of Nanjing University of Chinese Medicine Medical University (Nanjing, China).

Cell culture. The HeLa human cervical cancer line was purchased from the American Type Culture Collection (Manassas, VA, USA) and grown in DMEM, supplemented with $10 \%$ (v/v) heat-inactivated fetal bovine serum (FBS), $2 \mathrm{mmol} / \mathrm{L}$-glutamine, $100 \mathrm{U} / \mathrm{ml}$ penicillin, and $100 \mathrm{U} / \mathrm{ml}$ streptomycin (all from Gibco; Thermo Fisher Scientific, Inc.). The HeLa cells were incubated at $37^{\circ} \mathrm{C}$ in a humidified atmosphere with $5 \%$ carbon dioxide. The HeLa cells were subject to MTT assay upon reaching 70-80\% confluency.

Assessment of cell viability using an MTT assay. Upon reaching $\sim 80 \%$ confluency, the HeLa cells were treated with resveratrol in complete medium for dose-dependent and time-dependent studies. In the control group, the HeLa cells were treated with DMSO. The cytotoxicity-based MTT assay was performed according to previous reference (14). Briefly, $200 \mu \mathrm{l}$ of complete culture medium containing $2 \times 10^{4}$ cells was added to 96 -well microtiter plates and incubated with different concentrations $(0$, $5,10,20$ or $40 \mu \mathrm{M}$ ) resveratrol at $37^{\circ} \mathrm{C}$ in a humidified incubator. After 12, 24, 36 and $48 \mathrm{~h}$ of incubation with resveratrol, MTT was added and the cell samples were monitored at a wavelength of $595 \mathrm{~nm}$ on a scanning multiwell spectrophotometer. The effect of resveratrol on growth inhibition was assessed as the percentage of cell viability, and control cells treated with DMSO were considered $100 \%$ viable. Each assay was replicated 4 times and each experiment was repeated $\geq 3$ times.

Hoechst 33342 staining. The HeLa cells were seeded onto coverslips in 6-well plates at $5 \times 10^{4}$ cells per well and incubated at $37^{\circ} \mathrm{C}$. When the cells grown about $70-80 \%$ confluency, they were treated with $20 \mu \mathrm{M}$ resveratrol. After an incubation at $37^{\circ} \mathrm{C} 48 \mathrm{~h}$, the medium was aspirated and the coverslips were washed with PBS and treated with $20 \mu \mathrm{g} / \mathrm{ml}$ Hoechst 33342 at $37^{\circ} \mathrm{C}$ for $15 \mathrm{~min}$. Subsequently, the cells were washed with PBS and observed under a fluorescence microscope (Olympus Corporation, Tokyo, Japan).

Apoptosis detection. Cell apoptosis was evaluated using flow cytometry to quantify the levels of detectable phosphatidylserine on the outer membranes of apoptotic cells as previously reported (15). Briefly, the cells were grown to a density of $2 \times 10^{5}$ cells in $100 \mathrm{~mm}$ culture dishes and treated with $20 \mu \mathrm{M}$ resveratrol for $48 \mathrm{~h}$. The HeLa cells were trypsinized and washed twice with PBS, and then floating and adherent cells were collected and suspended in binding buffer (cat. no. 556547; BD Pharmingen; BD Biosciences, Franlink Lakes, NJ, USA) at $2 \times 10^{5}$ cells per $100 \mu \mathrm{l}$ binding buffer. Subsequently, the HeLa cells were stained using $5 \mu \mathrm{l}$ Annexin V-fluorescein isothiocyanate (FITC; cat. no. 556547; BD Pharmingen; BD Biosciences) in the dark at room temperature for $15 \mathrm{~min}$. Next, the cells were resuspended in $300 \mu \mathrm{l}$ binding buffer and stained with $10 \mu \mathrm{l}$ propidium iodide (PI; $50 \mu \mathrm{mol} / \mathrm{l}$ ). Annexin V/PI fluorescence was analyzed immediately with a flow cytometer. Per sample, $\geq 10,000$ events were counted, and the data presented as the proportion of early apoptotic cells $\left(\mathrm{FITC}^{+} / \mathrm{PI}^{-}\right)$

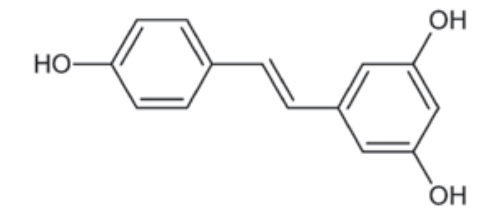

\author{
Molecular Formula $=\mathrm{C}_{14} \mathrm{H}_{12} \mathrm{O}_{3}$ \\ Formula Weight $=228.24328$ \\ Trans-Resveratrol (3,4`'5’'trihydroxystilbene)
}

Figure 1. Chemical structure of resveratrol.

and late apoptotic cells $\left(\mathrm{FITC}^{+} / \mathrm{PI}^{+}\right)$. The percentages of cells in the upper-right phase (late apoptotic cells), upper-left phase (necrotic cells), lower-right phase (early-apoptotic cells) and lower-left phase (viable cells) panels of the resulting histogram were calculated for comparison among these groups (Fig. 4).

Caspase -3 and -9 activity assay. Caspase- 3 or -9 activity was determined using Caspase Activity Assay kits (Biolife Co., Ltd., Beijing, China). Briefly, the cells were treated with 0, 5, 10,20 or $40 \mu \mathrm{M}$ resveratrol for $48 \mathrm{~h}$, washed twice with PBS, and digested with $0.25 \%$ trypsin-EDTA at $37^{\circ} \mathrm{C}$ for $1 \mathrm{~min}$. The cells were collected at a density of $3 \times 10^{6}$ by centrifugation at $100 \mathrm{x} \mathrm{g}$ at $4^{\circ} \mathrm{C}$ for $3 \mathrm{~min}$ and suspended in $100 \mu \mathrm{l}$ of ice-cold lysis buffer (cat. no. 89900; Thermo Fisher Scientific, Inc.). The cell lysates were incubated on ice for $10 \mathrm{~min}$ and centrifuged at $900 \mathrm{x} \mathrm{g}$ for $10 \mathrm{~min}$. The cell supernatants were collected and the protein concentration was determined using the Bradford method, based on standard reference BSA protein concentrations. The supernatant proteins $(50 \mu \mathrm{g})$ were added to 96 -well plates and incubated with caspase- 3 and -9 colorimetric substrate (Biolife Co., Ltd.) for $2 \mathrm{~h}$ at $37^{\circ} \mathrm{C}$. Subsequently, the absorbance was measured at a wavelength of $405 \mathrm{~nm}$ using a microplate reader (Titertek Multiskan Plus, Labsystems, Finland). All experiments were performed in triplicate.

Western blot analysis. Protein samples were dissolved in a sample buffer containing $0.5 \mathrm{M}$ Tris hydrochloride ( $\mathrm{pH} 6.8$ ), $20 \%$ glycerol, $2 \%$ SDS, $0.5 \%$ bromophenol blue and $10 \mathrm{mM}$ dithiothreitol. The protein concentrations of cell lysates were evaluated according to the Bradford method using bovine serum albumin as a standard. The proteins (40-100 $\mu \mathrm{g})$ were separated by $12 \%$ SDS-polyacrylamide gel electrophoresis, blotted on nitrocellulose (NC) membranes, and blocked with a solution of $5 \%(\mathrm{w} / \mathrm{v})$ skimmed milk powder and $0.1 \%(\mathrm{w} / \mathrm{v})$ Tween-20 in PBS ( $\mathrm{pH} \mathrm{7.5)} \mathrm{for} 1 \mathrm{~h}$ at room temperature. The $\mathrm{NC}$ membranes were incubated with the primary antibodies for $2 \mathrm{~h}$ at room temperature or overnight at $4^{\circ} \mathrm{C}$. Subsequently, the membranes were washed with $\mathrm{PBS}$ and incubated with the secondary antibody for $2 \mathrm{~h}$ at $4^{\circ} \mathrm{C}$ (16). Next, HRP substrate (dilution, 1:1,000) was added and the NC membranes were imaged (Kodak, Japan). The intensities of the bands were quantitated using Image $\mathrm{Lab}^{\mathrm{TM}}$ Image Analysis software on a Gel Doc ${ }^{\mathrm{TM}}$ system (version no. 170-8195; Bio-Rad Laboratories, Inc., Hercules, CA, USA). Molecular weight-markers were electroblotted and analyzed simultaneously.

Statistical analysis. All data were representative of $\geq 3$ independent experiments and are presented as the mean \pm standard 

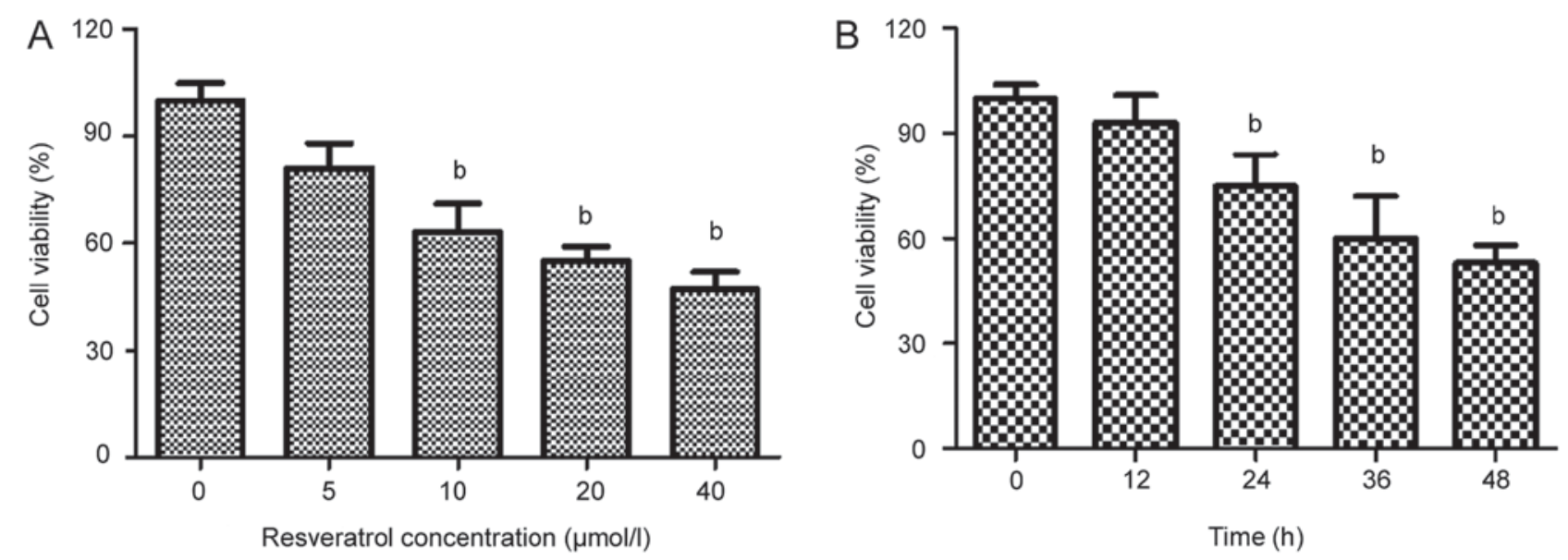

Figure 2. Cell cytotoxicity effects upon resveratrol-treatment in HeLa cells. (A) HeLa cells were incubated with resveratrol at concentrations of $0,5,10,20$ and $40 \mu \mathrm{mol} / 1$ for $48 \mathrm{~h}$ and cell viability was evaluated. (B) Cells were incubated with $20 \mu \mathrm{mol} / 1$ resveratrol for $0,12,24,36$ and $48 \mathrm{~h}$. Following incubation, cell viability was determined by an MTT assay. Results are presented as the mean \pm standard deviation of three separate experiments. ${ }^{b} \mathrm{P}<0.05$ vs. control.
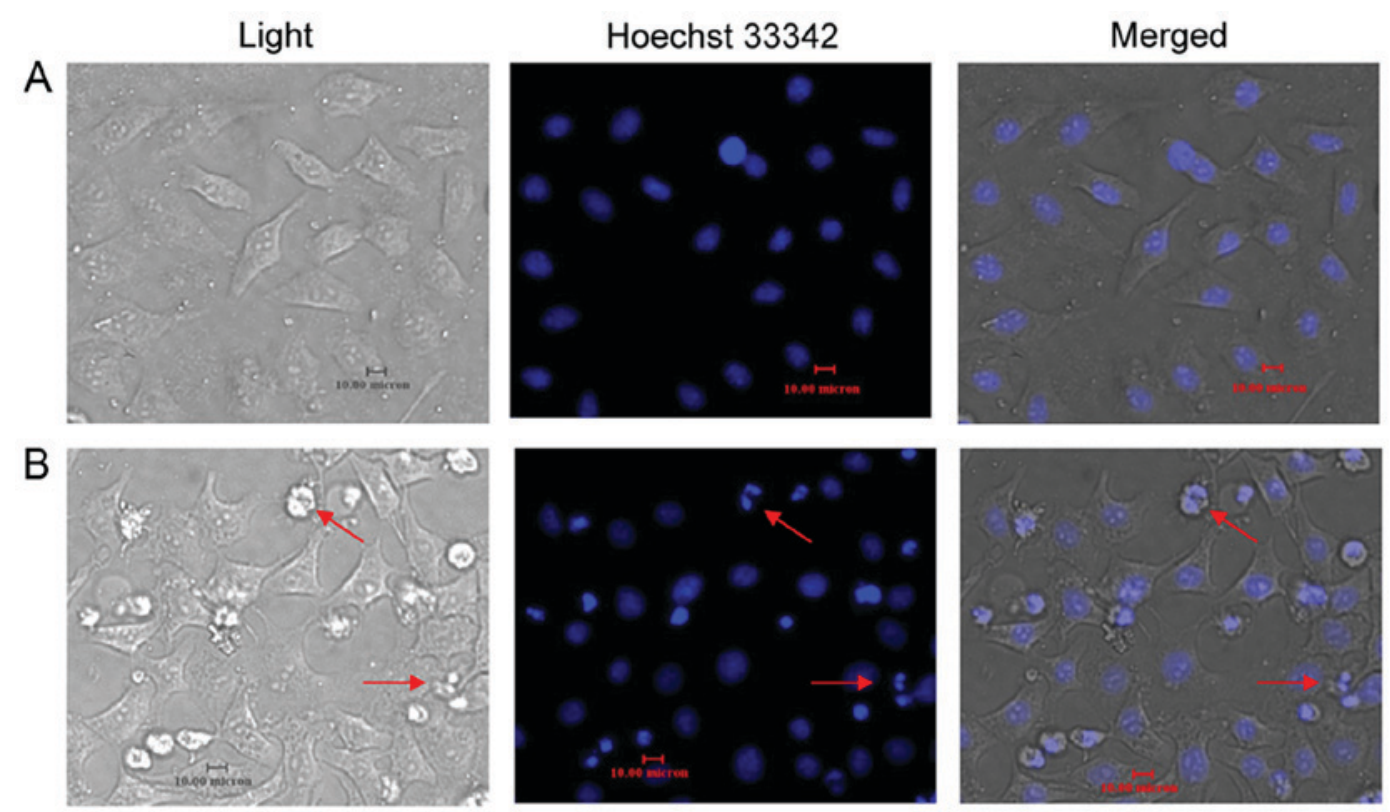

Figure 3. Resveratrol treatment induces apoptosis in HeLa cells. Hoechst 33342 fluorescence staining was used to detect apoptosis in HeLa cells treated with (A) vehicle or (B) $20 \mu \mathrm{M}$ resveratrol for $48 \mathrm{~h}$. Red arrows indicate the fragmentation of condensed nuclei occurring during apoptosis. Scale bar, $10 \mu \mathrm{m}$. Light, light microscopy; merged, merged fluorescence and light microscopy images.

deviation. The data were analyzed using SPSS version 11.5 for Windows (SPSS, Inc., Chicago, IL, USA). One-way analysis of variance or the Student's t-test was used to compare between the treatment and control groups. $\mathrm{P}<0.05$ was considered to indicate a statistically significant difference.

\section{Results}

Resveratrol inhibits the proliferation of HeLa cells. To identify the effects of resveratrol on HeLa cell survival, the cells were cultured in medium containing various concentrations of resveratrol $(0-40 \mu \mathrm{mol} / \mathrm{l})$ for $48 \mathrm{~h}$. Resveratrol treatment induced a concentration-dependent reduction in the viability of the HeLa cells (Fig. 2A). The survival rate of the HeLa cells treated with $20 \mu \mathrm{mol} / 1 \mathrm{resveratrol} \mathrm{was} \mathrm{reduced} \mathrm{after} 24 \mathrm{~h}$ (Fig. 2B). On the basis of the MTT assay results, resveratrol treatment at concentrations of 20,40 and $60 \mu \mathrm{mol} / 1$, and a $48 \mathrm{~h}$ incubation period, was selected for further mechanistic studies.

Resveratrol induces HeLa cell apoptosis. After 48 h of incubation with resveratrol $(20 \mu \mathrm{mol} / 1)$, Hoechst 33342 staining revealed increased apoptotic bodies and nuclear condensations in the HeLa cells (Fig. 3). Apoptosis was quantified by flow-cytometric analysis using Annexin V FITC/PI double staining in the HeLa cells treated with $20 \mu \mathrm{mol} / 1$ resveratrol at various time points. Resveratrol ( $0-40 \mu \mathrm{mol} / \mathrm{l})$ produced a concentration-dependent increase in the apoptotic cell population after $48 \mathrm{~h}$ of incubation. After $24 \mathrm{~h}$ of treatment with resveratrol, the counts of early (lower-right quadrant) and late (upper-right quadrant) apoptotic cells were increased in a concentration-dependent manner (Fig. 4). Almost $35 \%$ of 
A

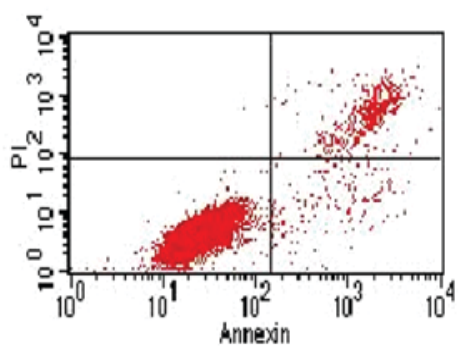

B

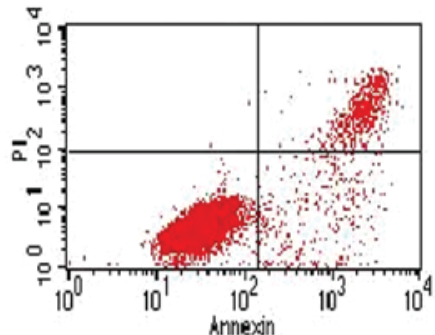

C

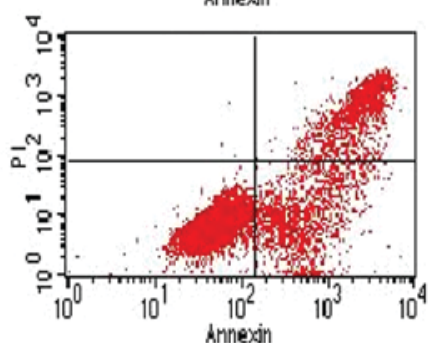

$34.16 \%$

Figure 4. Flow cytometry analysis of HeLa cells treated with $20 \mu \mathrm{mol} / 1$ resveratrol for (A) $0 \mathrm{~h}$ (B) $24 \mathrm{~h}$ and (C) $48 \mathrm{~h}$, with cell death rates of 3.89 , 12.23 and $34.16 \%$, respectively. PI, propidium iodide.

the HeLa cells had advanced to late apoptotic stages upon treatment with $60 \mu \mathrm{mol} / 1 \mathrm{resveratrol}$, compared with the vehicle-treated controls (Fig. 4).

Resveratrol upregulates the expression and activity of caspase-3 and -9 in HeLa cells. Following treatment with varying concentrations of resveratrol for $48 \mathrm{~h}$, the expression levels of caspase- 3 and -9 were increased in the HeLa cells (Fig. 5A). The expression levels of caspase-3 and -9 were upregulated in the resveratrol-treated $(20 \mu \mathrm{mol} / \mathrm{l}) \mathrm{HeLa}$ cells (Fig. 5B). Activation of caspase cascades was observed in the process of apoptosis. Subsequently, the HeLa cells were incubated with various concentrations of resveratrol for $48 \mathrm{~h}$ to examine caspase- 3 and -9 activity. The results revealed that

caspase-3-like and caspase-9-like cysteine protease activity increased during the process of resveratrol-induced apoptosis (Fig. 6).

Resveratrol alters the expression levels of Bcl-2 family proteins in the HeLa cells. The effect of resveratrol on the expression levels of the pro-apoptotic protein Bax and the anti-apoptotic proteins Bcl-2 and Bcl-XL was examined. Following treatment with resveratrol, the expression levels of Bax were increased, whereas the expression levels of Bcl-2 and Bcl-XL were decreased in a dose-dependent and time-dependent manner in the HeLa cells (Fig. 7).

Resveratrol upregulates p53 expression and downregulates cyclin B1 expression in HeLa cells. Western blot analysis revealed that p53 expression levels were gradually increased and Cyclin B1 expression levels were decreased $(\mathrm{P}<0.05)$ in a time-dependent manner in the resveratrol-treated $(20 \mu \mathrm{mol} / \mathrm{l})$ HeLa cells, as compared with in the vehicle control cells (Fig. 8).

\section{Discussion}

Chemotherapy using non-toxic natural components is a promising therapeutic strategy for the treatment of carcinoma. Recently, numerous studies have attempted to identify novel anticancer treatments obtained from natural products (17). Resveratrol, a natural polyphenolic phytoalexin, has been demonstrated to possess antioxidant, anti-atherosclerotic, anti-inflammatory (18) and anticancer properties (19-21). The chemopreventive efficacy of resveratrol has been identified in hepatocellular, lung, skin and prostate cancer, functioning through a number of underlying regulatory mechanisms (22-24). However, the precise mechanism of action of resveratrol in human cervical carcinoma remains to be investigated, limiting its therapeutic applications. In the present study, it was demonstrated that resveratrol significantly inhibited HeLa cell growth and induced apoptosis in a doseand time-dependent manner, and the cells exhibited hallmarks of apoptosis, including cell shrinkage, DNA fragmentation and formation of apoptotic bodies.

Numerous external and internal stimuli may trigger cell apoptosis via the activation of caspases. In the process of caspase- 9 activation, cytochrome $c$ binds to apoptosis activating
A

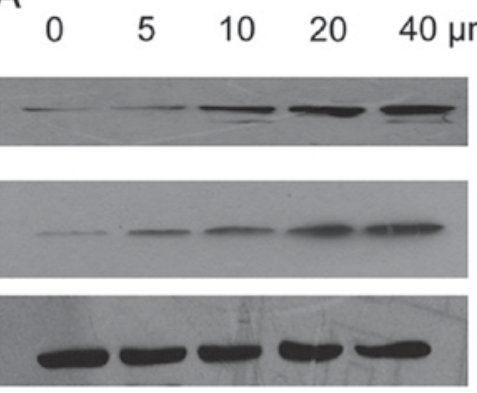

B $\begin{array}{lllll}0 & 12 & 24 & 36 & 48 \mathrm{~h}\end{array}$

caspase-3

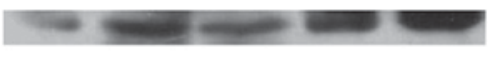

caspase-9

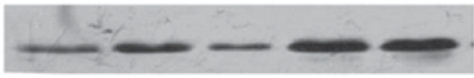

$\beta$-actin

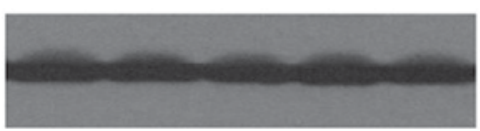

Figure 5. Western blot analysis of caspase-3 and -9 protein expression levels in resveratrol-treated HeLa cells. (A) Cells were exposed to $0,5,10,20$ and $40 \mu \mathrm{mol} / 1$ of resveratrol for $48 \mathrm{~h}$. (B) Cells were treated with $20 \mu \mathrm{mol} / 1$ resveratrol for $0,12,24,36$ and $48 \mathrm{~h}$. Cells were lysed, and equal quantities of protein were separated using $12 \%$ SDS-PAGE prior to protein expression being detected by western blotting. 
A

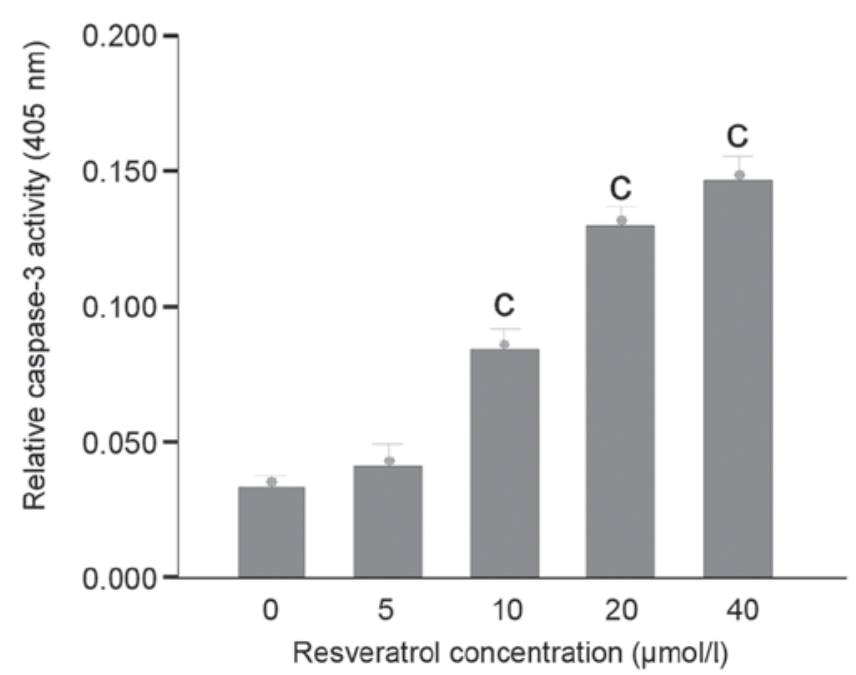

B

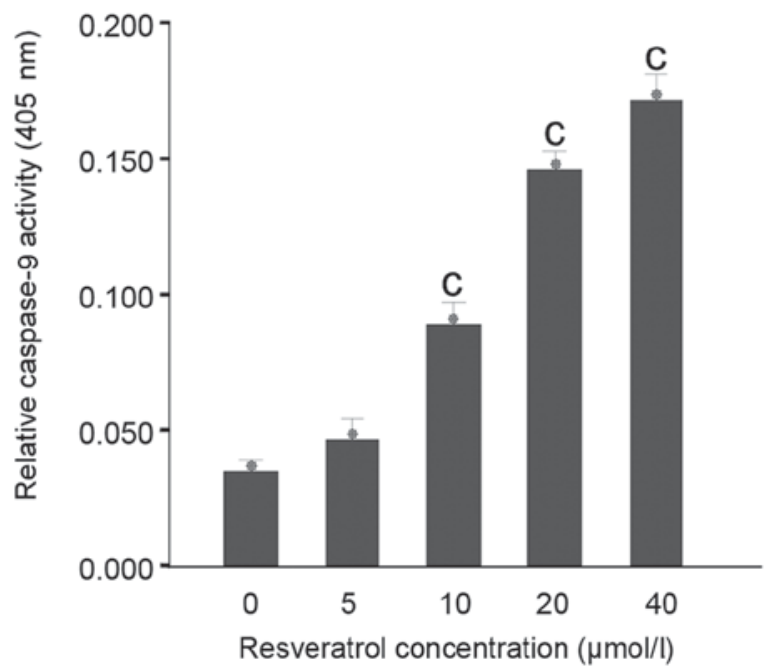

Figure 6. Resveratrol-induced caspase-3 and -9 activation in HeLa cells. HeLa cells were treated with $0,5,10,20$ and $40 \mu$ mol/1 of resveratrol for 48 h. Cell extracts $(50 \mu \mathrm{g})$ were then incubated in the presence of fluorescent (A) caspase-3 substrate, Ac-DEVDMCA and (B) caspase-9 substrate, Ac-LEHD-MCA for $4 \mathrm{~h}$ at $37^{\circ} \mathrm{C}$. Absorbance was measured at a wavelength of $405 \mathrm{~nm}$ using a microplate reader. Results are presented as the mean \pm standard deviation of three separate experiments. ${ }^{\mathrm{C}} \mathrm{P}<0.05$ vs. Control.
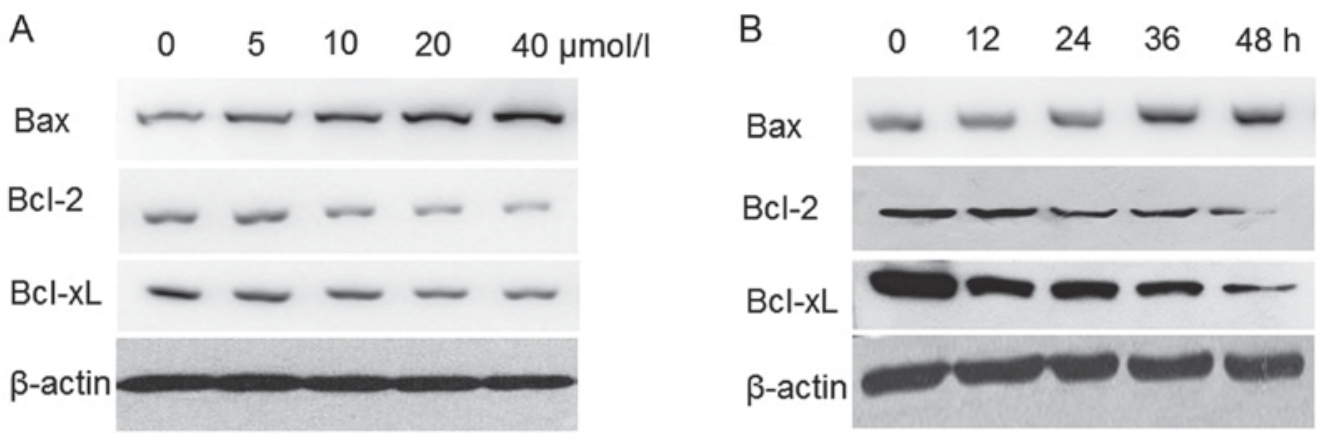

Figure 7. Western blot analysis of Bax, Bcl-2 and Bcl-XL protein expression levels in resveratrol-treated HeLa cells. (A) Cells were exposed to $0,5,10,20$ and $40 \mu \mathrm{mol} / 1$ of resveratrol for $48 \mathrm{~h}$. (B) Cells were treated with $20 \mu \mathrm{mol} / 1$ resveratrol for $0,12,24,36$ and $48 \mathrm{~h}$. All cells were lysed, equal quantities of protein were separated using $12 \%$ SDS-PAGE and protein expression was detected by western blotting. Bcl-2, B-cell lymphoma 2; Bax, B-cell lymphoma 2-associated $\mathrm{X}$ protein; Bcl-2 XL, B-cell lymphoma 2-extra large.

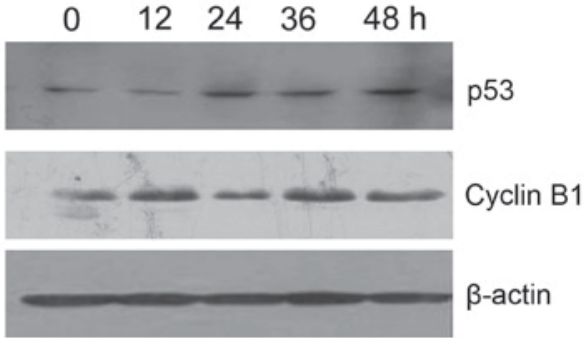

Figure 8. Western blot analysis of p53 and cyclin B1 protein expression levels in resveratrol-treated HeLa cells. Cells were treated with $20 \mu \mathrm{mol} / 1$ of resveratrol for $0,12,24,36$ and $48 \mathrm{~h}$ All cells were lysed, equal quantities of protein were separated using $12 \%$ SDS-PAGE and protein expression was detected by western blotting.

factor 1 and procaspase-9 to form an apoptosome complex, which further activates the downstream effector caspase-3 (25). Caspase- 8 and -9 are regarded as initiator caspases, and activate additional effector caspases, including caspase- 6 and -7 (26). The activation of caspases leads to the cleavage of a set of proteins, including poly (ADP-ribose) polymerase, and the disassembly of cell components, including the fragmentation of DNA (27). The overexpression of Bcl-2 or Bcl-XL results in the inhibition of cytochrome $c$ release and termination of the apoptotic response, whereas the overexpression of Bax or its Bcl-2 homologous domain 3 promotes cytochrome $c$ release $(28,29)$. The present study revealed that resveratrol-treatment was able to significantly increase the activation of caspase-3 and -9, decrease Bcl-2 and Bcl-XL protein levels and increase Bax protein levels $(\mathrm{P}<0.05)$. These findings suggest that Bcl- 2 family proteins, as well as caspase- 3 and -9 , are involved in the process of resveratrol-induced apoptosis.

The cell cycle includes four phases progressing from quiescence $\left(G_{0}\right.$ phase) to proliferation $\left(G_{1}, S, G_{2}\right.$ and $M$ phases), which are driven by the sequential activation of cyclin-dependent kinase (CDK) and its cofactor cyclins. CDK-cyclin B1 complexes are essential for the phosphorylation of a variety of proteins involved in mitotic events, including nuclear envelope breakdown, chromosomal condensation, spindle formation and the attachment of chromosomes to spindle fibers (30). 
Therefore, cell cycle proteins, including cyclin B1 and CDK1, are associated with the $\mathrm{G}_{2} / \mathrm{M}$ phase of the cell cycle (31). p53, a tumor suppressor gene, is activated during cellular stresses, including hypoxia, carcinogenesis and oxidative stress, functioning by inhibiting cell cycle progression and activating the DNA repair machinery to promote cell survival and maintain genome integrity. A p53-dependent arrest occurring at the $\mathrm{G}_{2}$ phase of the cell cycle is associated with a proteasome-dependent decrease in cyclin B1 protein levels $(32,33)$. In addition, a p53-dependent increase in $\mathrm{p} 21$ protein levels is associated with a decrease in cyclin B1 protein levels $(34,35)$. The results of the present study revealed that resveratrol was able to induce $\mathrm{G}_{2} / \mathrm{M}$ phase arrest in HeLa cells. To investigate the association between $\mathrm{G}_{2} / \mathrm{M}$ phase arrest and cyclin B1 expression levels, the effect of resveratrol on cyclin B1 proteins was examined. The results revealed that resveratrol treatment significantly decreased $(\mathrm{P}<0.05)$ the expression levels of cyclin $\mathrm{B} 1$ protein in HeLa cells, leading to a significant reduction $(\mathrm{P}<0.05)$ in the formation of CDK1-cyclin B complexes and $\mathrm{G}_{2} / \mathrm{M}$ phase cell cycle arrest. In summary, the present study demonstrated that resveratrol is able to increase the expression levels of p53 in HeLa cells in order to inhibit cell cycle progression and activate DNA repair machinery to promote cell survival and maintain genome integrity.

In conclusion, the results of the present study support the hypothesis that resveratrol downregulates the expression levels of the essential signaling proteins Bcl-2 and Bcl-XL, which are involved in the proliferation and survival of HeLa cells. Furthermore, resveratrol treatment promotes apoptosis by increasing the levels of caspase- 3 and -9 and $\mathrm{p} 53$ protein expression in HeLa cells. In summary, resveratrol may induce cell cycle arrest and apoptosis in HeLa cells through activation of the mitochondrial apoptosis signaling pathway, accompanied by the upregulation of $\mathrm{p} 53$ expression and downregulation of cyclin B1 expression. Therefore, resveratrol may be a promising novel inhibitor of human cervical cancer.

\section{Acknowledgements}

The authors would like to thank Professor Li Zhang for her guidance, and Professor Li-Yun Shi and laboratory members for discussion and insightful comments.

\section{Funding}

This study was supported by the National Natural Science Foundation of China (grant nos. 30371727, 30973940, 30772766 and 81001599).

\section{Availability of data and materials}

The datasets used and/or analyzed during the current study are available from the corresponding author on reasonable request.

\section{Authors' contributions}

LL contributed to study design, performed experiments, data analysis and writing of the manuscript. RLQ made substantial contributions to the conception and design of the study, performed experiments and writing of the manuscript. YL contributed to study design, performed experiments and critically revised the manuscript. YC performed experiments, and data analysis and interpretation. YB analyzed data and contributed to writing of the manuscript. YF and XJG performed experiments and data analysis. All authors read and approved the final manuscript.

\section{Ethics approval and consent to participate}

Not applicable.

\section{Consent for publication}

Not applicable.

\section{Competing interests}

The authors declare that they have no competing interest.

\section{References}

1. Brisdelli F, D'Andrea G and Bozzi A: Resveratrol: A natural polyphenol with multiple chemopreventive properties. Curr Drug Metab 10: 530-546, 2009.

2. Pineda-Sanabria SE, Robertson IM and Sykes BD: Structure of trans-resveratrol in complex with the cardiac regulatory protein troponin C. Biochemistry 50: 1309-1320, 2011

3. Khurana S, Venkataraman K, Hollingsworth A, Piche M and Tai TC: Polyphenols: Benefits to the cardiovascular system in health and in aging. Nutrients 5: 3779-3827, 2013.

4. Bollmann F, Art J, Henke J, Schrick K, Besche V, Bros M, Li H, Siuda D, Handler N, Bauer F, et al: Resveratrol post-transcriptionally regulates pro-inflammatory gene expression via regulation of KSRP RNA binding activity. Nucleic Acids Res 42: 12555-12569, 2014.

5. Fresco P, Borges F, Diniz C and Marques MP: New insights on the anticancer properties of dietary polyphenols. Med Res Rev 26: 747-766, 2006.

6. Singh CK, George SJ and Ahmad N: Resveratrol-based combinatorial strategies for cancer management. Ann N Y Acad Sci 1290: 113-121, 2013.

7. De Amicis F, Giordano F, Vivacqua A, Pellegrino M, Panno ML, Tramontano D, Fuqua SA and Andò S: Resveratrol, through $\mathrm{NF}-\mathrm{Y} / \mathrm{p} 53 / \mathrm{Sin} 3 / \mathrm{HDAC} 1$ complex phosphorylation, inhibits estrogen receptor alpha gene expression via p38MAPK/CK2 signaling in human breast cancer cells. FASEB J 25: 3695-3707, 2011.

8. Damianaki A, Bakogeorgou E, Kampa M, Notas G, Hatzoglou A, Panagiotou S, Gemetzi C, Kouroumalis E, Martin PM and Castanas E: Potent inhibitory action of red wine polyphenols on human breast cancer cells. J Cell Biochem 78: 429-441, 2000.

9. Pandey PR, Okuda H, Watabe M, Pai SK, Liu W, Kobayashi A, Xing F, Fukuda K, Hirota S, Sugai T, et al: Resveratrol suppresses growth of cancer stem-like cells by inhibiting fatty acid synthase. Breast Cancer Res Treat 130: 387-398, 2011.

10. Bae S, Lee EM, Cha HJ, Kim K, Yoon Y, Lee H, Kim J, Kim YJ, Lee HG, Jeung HK, et al: Resveratrol alters microRNA expression profiles in A549 human non-small cell lung cancer cells. Mol Cells 32: 243-249, 2011.

11. Hsieh TC and Wu JM: Differential effects on growth, cell cycle arrest, and induction of apoptosis by resveratrol in human prostate cancer cell lines. Exp Cell Res 249: 109-115, 1999.

12. Li G, Rivas P, Bedolla R, Thapa D, Reddick RL, Ghosh R and Kumar AP: Dietary resveratrol prevents development of high-grade prostatic intraepithelial neoplastic lesions: Involvement of SIRT1/S6K axis. Cancer Prev Res (Phila) 6: 27-39, 2013.

13. Torre LA, Bray F, Siege RL, Ferlay J, Lortet-Tieulent J and Jemal A: Global cancer statistics, 2012. CA Cancer J Clin 65: 87-108, 2015.

14. Berridge MV, Herst PM and Tan AS: Tetrazolium dyes as tools in cell biology: New insights into their cellular reduction. Biotechnol Annu Rev 11: 127-152, 2005. 
15. Nicoletti I, Migliorati G, Pagliacci MC, Grignani F and Riccardi C: A rapid and simple mothed for measuring thymocyte apoptosis by propidum iodide staining and flow cytometry. J Immonuol Methods 139: 271-279, 1991.

16. Khan A, Khan AA, Dwivedi V, Ahmad MG, Hakeem S and Owais M: Tuftsin augments antitumor efficacy of liposomized etoposide against fibrosarcoma in Swiss albino mice. Mol Med 13: 266-276, 2007.

17. Fang J, Cai C, Wang Q, Lin P, Zhao Z and Cheng F: Systems pharmacology-based discovery of natural products for precision oncology through targeting cancer mutated genes. CPT Pharmacometrics Syst Pharmacol 6: 177-187, 2017.

18. Soleas GL, Grass L, Josephy PD, Goldberg DM and Diamandis EP: A comparison of the anticarcinogentic properties of four red wine polyphenols. Clin Biochem 35: 119-124, 2002.

19. She QB, Bode AM, Ma WY, Chen NY and Dong Z: Resveratrolinduced activation of P53 and apoptosis is mediated by extracellular-single-regulated protein kinase and P38 kinase. Cancer Res 61: 1604-1610, 2001

20. Surh YJ,Hurh YJ,Kang JK,Lee E, Kong G and Lee SJ: Resveratrol, an antioxidant present in red wine, induces apoptosis in human promyelocytic leukemia (HL-60) cells. Cancer Lett 140: 1-10, 1999.

21. Clément MV, Hirpara JL, Chawdhury SH and Pervaiz S: Chemopreventive agent resveratrol, a natural product derived from grapes, triggers CD95 signaling-dependent apoptosis in human tumor cells. Blood 92: 996-1002, 1998 .

22. Seeni A, Takahashi S, Takeshita K, Tang M, Sugiura S, Sato SY and Shirai T: Suppression of prostate cancer growth by resveratol in the transgenic rat for adenocarcinoma of prostate (TRAP) model. Asisan Pac J cancer Prev 9: 7-14, 2008.

23. Liu H, Zang C, Fenner MH, Liu D, Possinger K, Koeffler HP and Elstner E: Growth inhibition and apoptosis in human Philadelphia chromosome-positive lymphoblastic leukemia cell lines by treatment with the dual PPARalpha/gamma ligand TZD18. Blood 107: 3683-3692, 2006.

24. Roy P,Kalra N,Prasad S, George J and Shukla Y: Chemopreventive potential of Resveratrol in mouse skin tumors through regulation of mitochondrial and PI3K/AKT signaling pathways. Pharm Res 26: 211-217, 2009.

25. Kidd VJ: Proteolytic activities that mediate apoptosis. Annu Rev Physiol 60: 533-573, 1998.
26. Kurokawa $\mathrm{M}$ and Kornbluth S: Caspases and kinases in a death grip. Cell 138: 838-854, 2009.

27. Kook S, Zhan X, Cleghorn WM, Benovic JL, Gurevich VV and Gurevich EV: Caspase-cleaved arrestin-2 and BID cooperatively facilitate cytochrome $C$ release and cell death. Cell Death Differ 21: 172-184, 2014.

28. Xiong S, Mu T, Wang G and Jiang X: Mitochondria-mediated apoptosis in mammals. Protein Cell 5: 737-749, 2014.

29. Liu J, Li Y, Ren W and Hu WX: Apoptosis of HL-60 cells induced by extracts from Narcissus tazetta var. chinensis. Cancer Lett 242: 133-140, 2006.

30. Hiraoka D, Aono R, Hanada S, Okumura E and Kishimoto T: Two new competing pathways establish the threshold for cyclin-B-Cdk1 activation at the meiotic G2/M transition. J Cell Sci 129: 3153-3166, 2016.

31. Pal HC, Sharma S, Elmets CA, Athar M and Afaq F: Fisetin inhibits growth, induces $\mathrm{G}_{2} / \mathrm{M}$ arrest and apoptosis of human epidermoid carcinoma A431 cells: Role of mitochondrial membrane potential disruption and consequent caspases activation. Exp Dermatol 22: 470-475, 2013.

32. Bhattacharya S, Ray RM and Johnson LR: Cyclin-dependent kinases regulate apoptosis of intestinal epithelial cells. Apoptosis 19: 451-466, 2014

33. Zhang Z, Wang CZ, Du GJ, Qi LW, Calway T, He TC, Du W and Yuan CS: Genistein induces G2/M cell cycle arrest and apoptosis via ATM/p53-dependent pathway in human colon cancer cells. Int J Oncol 43: 289-296, 2013.

34. Charrier-Savournin FB, Château MT, Gire V, Sedivy J, Piette J and Dulic V: p21-mediated nuclear retention of cyclin B1-Cdk1 in response to genotoxic stress. Mol Biol Cell 15: 3965-3976, 2004.

35. Chae SW, Sohn JH, Kim DH, Choi YJ, Park YL, Kim K, Cho YH, Pyo JS and Kim JH: Overexpressions of cyclin B1, cde2, p16 and p53 in human breast cancer: The clinicopathologic correlations and prognostic implications. Yonsei Med J 52: 445-453, 2011.

(c) (i)(9) This work is licensed under a Creative Commons (c) At ${ }_{\mathrm{EY}} \mathrm{NO}$ Atribution-NonCommercial-NoDerivatives 4.0 International (CC BY-NC-ND 4.0) License. 